\title{
Women, class, and the language of madness in early modern English drama
}

\author{
Sandra Clark \\ Institute of English Studies \\ University of London
}

\begin{abstract}
This paper discusses the depiction of madwomen in a range of early modern English plays including some by Shakespeare in order to show how their madness operates at the intersection of gender, genre, and social class. Its particular focus is on language, and it argues that the speech styles of madwomen are essentially similar whatever their social class. For women, madness is a linguistically liberating condition, bringing together high and low cultural discourses. While stage madwomen's language has similarities with that of madmen, it is more licentious and transgressive because the violation of social and behavioural norms is more extreme.
\end{abstract}

KEYWORDS: madness; language; nonsense; transgression; taboo; impertinency; popular tradition; ballads; gender; liberation; imagination; sexuality.

One aim of this paper is to reconsider the depiction of madwomen and significance of their speech styles in early modern plays by thinking about how their madness operates at the intersection of gender, genre and social class. Recent accounts of the depiction of mental disorder in female characters focus particularly on Ophelia in Hamlet and the Jailor's Daughter in The Two Noble Kinsmen, comparing them so as to bring out their class difference; there is also a pronounced stress on the origins of female madness in

$$
\text { Sederi } 24 \text { (2014: 7-26) }
$$


lovesickness. ${ }^{1}$ By broadening the discussion to other characters, I hope also to shift the emphasis from this diagnosis and to consider other cultural implications of the language of madness. Carol Thomas Neely has already described this effectively:

This speech is something and "nothing;" both coherent and incoherent $[. .$.$] characterized by fragmentation, repetition, and$ most importantly by [...] "cultural quotation" [...]. The prose that is used for this mad speech (although it includes embedded songs and rhymes) implies disorderly shape, associates madness with popular tradition, and contributes to its colloquial, "quoted" character. (Neely 2004:50)

She does not explicitly say that these observations apply mainly to the speech of women rather than men, although her subsequent discussion makes this clear. ${ }^{2}$ One of the things that mad or distracted women in plays of this period notably do, like Lady Macbeth, is to speak what they should not, but the manner in which their transgressive utterances are voiced is as important as the content. Edgar in King Lear describes one of Lear's mad pronouncements as "matter and impertinency mixed" (4.6.170). "Impertinency" means something more than "nonsense" (as the Arden editor glosses it), and one important aspect is that it is indecorous; mad characters of high social rank often use words and forms of language that are low, childish or in other ways socially inappropriate. This element is even more pronounced in the language of women. It may be related to what Jean-Jacques Lecercle in his study, The Violence of Language, terms "the remainder," where "language is no longer a mere instrument, it seems to have acquired a life of its own. Language speaks, it follows its own rhythm, its own partial coherence, it proliferates in apparent, and sometimes violent, chaos" (5). . By looking more closely at the elements of "impertinency" in the speech

\footnotetext{
${ }^{1}$ See for instance Dawson (2008) and Charney and Charney (1977:451-460). Neely in her excellent book, Distracted Subjects: Madness and Gender in Shakespeare and Early Modern Culture (2004:83), differentiates between the madness of Ophelia and the Jailor's Daughter, characterising the latter as "delusional female melancholy."

${ }^{2}$ The only male character cited, who uses similar mad speech, is Edgar in King Lear when playing the role of Poor Tom.

${ }^{3}$ Lecercle's brief account of the writing of Unica Zürn, who suffered from mental illness, illustrating how a "mad" speaker "is not in full control of her words, she follows the path that language opens up for her" (58-59) has some relevance to the language of stage madwomen.
} 
of madwomen, and at the relation of this speech to popular tradition, I want to examine linkages between women's madness and licence and their role in producing a discourse that is carnivalesque in the Bakhtinian sense of the term, subversive of norms of distinction and hierarchy, and liberating. ${ }^{4}$

"Interest in insanity quickened about 1580, and madmen, melancholics, and suicides became familiar literary types" (MacDonald 1981:2). ${ }^{5}$ Thus Michael MacDonald, the social historian, begins his illuminating account of the medical work of the astrological physician Richard Napier, who specialised in the treatment of mental disorders. It was a period when medical practice was regularly informed by what now appear to be competing discourses: astrology, magic and religion as well as science, a situation due to change later in the century. There were varying views of the origins of madness; it might be physical, accountable in terms of Galenic medicine to humoral imbalance, or spiritual, as divine retribution for a sinful conscience. ${ }^{6}$ There was believed to be a form of mental disorder specific to women when the menstrual flow, if not released by sexual intercourse, would putrify and cause noxious vapours to ascend to the brain. ${ }^{7}$ As can be inferred from the records of the practices of astrological physicians of the period, such as Simon Forman, William Lilly and especially Richard Napier, ${ }^{8}$ who were consulted by members of all classes, the readings of bodily disturbance applied across the social spectrum; the symptoms of madness were subject to the same processes of interpretation

\footnotetext{
${ }^{4}$ Bakhtin (1984) defines his view of the carnivalesque in the Introduction to his book on Rabelais. His account of "billingsgate," "the familiar speech of the marketplace" (16), has some similarities with the speech styles I discuss.

${ }^{5}$ See also Neely (2004:2), on distracted subjects as "an urgent focus of representation" in the period.

${ }^{6}$ For more detail, see Peterson (2010:35-59), and Iyengar (2011), entry on "madness." These accounts are of greater relevance to my discussion than Foucault's vague theorising about "the tragic experience of madness" (1971:31) in the Renaissance period.

${ }^{7}$ Iyengar, "hysterica passio."

${ }^{8}$ Macdonald stresses that Napier's patients were "mostly people of humble social standing" (1981:36). He discusses their social status on more detail on pp. 48-54. See also Thomas (1973:375-382). Thomas gives figures from Lilly's records for a period of 28 months between 1654 and 1656 showing that while 124 people classified as "gentry and above" consulted him, there were also 254 female servants (1973:379, n.192).
} 
whatever the social class of the sufferer. Madness, declared Robert Burton in The Anatomy of Melancholy, is a universal affliction: "kingdoms and provinces are melancholy, cities and families, all creatures, vegetal, sensible, and rational, [...] all sorts, sects, ages , conditions, are out of tune"(Burton 1972:1.39). In early modern England, for all its rigidity of social differentiation, temperaments were not socially conditioned; the psychopathology of the emotions, or, as they were then known, the passions, was the same for all classes. Medical treatises such as A Table of Humane Passions. With their Causes and Effects (1621) by Nicholas Coeffeteau, written for an educated audience, might pay more attention to conditions affecting the upper classes, but the aetiology was the same for all. In any account of madness and mental disorder there are distinctions to be made, in terms of gender as well as of social class, but they do not emanate from the physical origin of the condition. Michael MacDonald shows that the upper class and working class patients of Richard Napier differed little in the symptoms with which they consulted him, even if the terminology might be different. ${ }^{9}$ While Burton in The Anatomy of Melancholy considers lower class working women ("an hired servant, a poor handmaid[...] a coarse country wench") to be less prone to melancholy than "noble virgins, nice gentlewomen," he locates the prime cause of this in a physically active lifestyle, not any constitutional difference (Burton 1972:1, 417 (1.iii.2.(4)). ${ }^{10}$ Madness in King Lear is "a sight most pitiful in the meanest wretch|Past speaking in a king," because Lear's condition impacts not just on his own body but also on the body politic. "Never alone|Did the king sigh, but with a general groan," as Rosencrantz puts it in Hamlet.

Onstage, gender is more significant as a distinguishing feature of the handling of madness than social class. The point about the widespread impact of a king's madness applies by analogy to the madness of men in comparison to that of women. Men's functionality is more socially significant than women's. In plays such as The Spanish Tragedy, Hamlet, The White Devil, The Pilgrim, male and female madness are implicitly contrasted. In The Spanish Tragedy

\footnotetext{
${ }^{9}$ See MacDonald (1981:ch.3). Napier categorised his patients in three groups as Peers and Knights, $\mathrm{Mr}$ and Mrs, and No Title. The majority came from the third category.

${ }^{10}$ See the discussion of Burton's section on women's melancholy, added to his third edition (1628) in Neely (2004:91-93).
} 
Hieronimo's madness is a subject of consternation to the king and court and a cause of public scandal, but it empowers him in his quest for revenge. Isabella's madness is witnessed by no-one other than her maid, and her desire for revenge for her murdered son is turned against her own body: she cuts down the arbour where Horatio was hanged then kills herself:

And as I curse this tree from further fruit,

So shall my womb be cursed for his sake;

And with this weapon will I wound the breast,

The hapless breast that gave Horatio suck. (4.12.35-38).

Hamlet's madness is, in the view of Claudius, so dangerous to the state that it warrants, or at least can serve as an excuse for, the "desperate appliance" (4.3.10) of sending him out of the country. Ophelia must be watched and guarded, but does not pose the same threat. The nature of their mental disorders is also contrasted. Lesel Dawson characterises Hamlet's state of mind (perhaps too broadly) as "melancholy, which is cerebral, bookish, and philosophical" whereas Ophelia suffers from "madness [...] [which is] corporal, emotional and sexual" (75). In Neely's view, Ophelia "acts out the madness [Hamlet] only plays with" (54). This distinction is debatable, and Hamlet does not at all times demonstrate the degree of rational control over his conduct that it implies. Ophelia, witnessing his violently emotional (and misogynistic) outbursts in 3 . 1 , thinks that his "noble and most sovereign reason" has been "blasted with ecstasy" (3.1.157-159). But for Neely and Dawson a primary distinguishing quality of women's madness as represented in Ophelia (and anticipated in Isabella), comes from the association of her condition with that of female hysterics, when Ophelia's bodylanguage, her "winks and nods and gestures" (4.5.11), mimics that of women suffering from fits of that uterine disorder known as the mother (Neely 2004:52; Dawson 2008:72-79). Female body-language is certainly a primary signifier of meaning, and the simple stage direction in the 1592 edition of The Spanish Tragedy, "She runs lunatic" (3.8.5), indicates that the stage had already developed visual codes for female madness. ${ }^{11}$

\footnotetext{
${ }^{11}$ In George Peele's The Old Wives Tale (printed 1595, written between 1591 and 1594) there appears the stage direction, "Enter Venelia his lady, mad; and goes in again" (225). Venelia never speaks.
} 
But not all female characters who exhibit the symptoms of madness, real or feigned, suffer from uterine disorders or lovesickness: for example, Zabina in Tamburlaine, Pandora in The Woman in the Moon, Lucibella in The Tragedy of Hoffman, Cornelia in The White Devil, Anne Ratcliffe in The Witch of Edmonton exhibit symptoms of madness arising from quite different causes, and the gendered element in their madness is defined not by their pathology but by their codified conduct and their speech.

Zabina in Tamburlaine, part 1 , who goes mad at the sight of her husband's dead body, is probably the first madwoman on the early modern stage. ${ }^{12}$ Having left the stage at the request of Bajazeth, who has been imprisoned in a cage by Tamburlaine and asks for water, she returns to find that he has dashed his brains out on the bars of the cage. The onset of her madness is almost instantaneous; her loss of reason is signified in a descent into disjointed prose - metrically conspicuous in a largely verse play - which reflects recent bloody events in the play and the grotesque humiliations heaped on her and her husband by Tamburlaine. Before following her husband in suicide she curses Tamburlaine, then reverts to her sense of the rank he has violated: "Hell, death, Tamburlaine, hell! Make ready my coach, my chair, my jewels. I come, I come, I come!" (5.1.317-19). Zabina's short speech, with its repetitions, its mad mix of verse and prose and deranged recollections of recent experience, is a strong influence on the language of later women suffering from mental disorder. Isabella in The Spanish Tragedy does not share her syntactic incoherence but is similarly vividly fanciful, asking for herbs capable of purging her heart and imagining her soul ascending with "silver wings" to heaven, where her dead son Horatio sits, "Backed with a troop of fiery cherubins, | Dancing about his newly-healed wounds" (3.8.18-19). Madwomen's speech, unconstrained by reason and logic, is characterised also by imaginative freedom.

As with Zabina and Isabella, grief for loss is the immediate motivation for the madness of Lucibella in Chettle's play, The Tragedy of Hoffman, and Ophelia in Hamlet. The two plays are closely

\footnotetext{
${ }^{12}$ Both parts of Tamburlaine were published in 1590 but possibly written up to two years earlier. The first edition of The Spanish Tragedy was printed without date but probably in 1592, although the composition has been dated between 1582 and 1591 . For discussions of the dating see Marlowe, Tamburlaine (1981:20-22) and Kyd, The Spanish Tragedy (1970:xv-xvii).
} 
related, and although there are some dating problems, it seems clear that it is Chettle who is the dependent. ${ }^{13}$ Lucibella is the first madwoman of many to be influenced by Ophelia, and their mad scenes are similarly contextualised: each acts out her grief for a murdered father and a lost lover (Ophelia's through his apparent betrayal, Lucibella's through murder) before witnesses, some of whom bear a certain culpability for her condition. Lucibella's first lines of mad speech adopt several motifs from Ophelia's:

I pray you kill me not,

For I am going to the rivers side

To fetch white lilies, and blew daffodils

To stick in Lodowicks bosom, where it bled,

And in mine owne; my true love is not dead,

Noe y'are deceivd in him, my father is. (1431-1436)

Along with the flowers, the river, the preoccupation with death, Lucibella shares Ophelia's fears about inadequate mourning for the dead and incomplete burial rites, and her sense of mischief at work around her. "There's tricks i'th'world" (Hamlet 4.5.5), claims Ophelia. Lucibella is certain that "there's knaves abroad," and, unknowingly addressing the disguised Hoffman, the man responsible for the deaths of her father and lover, asks him

how thinke you goodly Prince,

God give you joy of your adoption;

May not trickes be usd? (1473-1475)

To which his response, "Alas poore Lady," recalls the uneasy attempts of Claudius to silence Ophelia with "How do you, pretty lady?" and "Pretty Ophelia." Both women disconcert the circle of observers around them with their language of madness, characterised by a mixture of "distracted prose" (Levin 2004:275) and verse, effects of babble, alliteration, internal rhymes and word-play, singing and the use of proverbial expressions and low terms. "Lye, lyer, licke dish" (2046), says Lucibella, reproving Hoffman's sidekick

13 The play was first printed, anonymously, in 1631. Henslowe's Diary for 29 December 1602 records a payment to "harey chettle [...] for a tragedie called Hawghman," assumed to be Hoffman, which may not yet have been complete. It probably postdates Hamlet Q2 (printed 1604 but composed earlier) but not necessarily Hamlet Q1, printed 1603. For discussion of the dating issues, see Thorndike (1902:125220).

${ }^{14}$ Quotations from The Tragedy of Hoffman are taken from the edition by Jenkins (1951). 
Lorrique, for his falsehoods. And when the duchess Martha asks Lorrique what he has done, Lucibella interrupts, saying, "Knavery, I warrant you, tell truth and shame the Divell my boy, doe, and thou shalt have a fine thing by and by" (2085-2087). Her speech has that quality that Polonius uneasily recognises in Hamlet when he remarks, "How very pregnant sometimes his replies are" (2.2.208209). Ophelia's use of language that is indecorous and distinctly inappropriate to a woman of her social status is more marked. In the words of the waiting Gentleman, she "hems, and beats her heart,|Spurns enviously at straws, speaks things in doubt|That carry but half sense" (4.5.5-7). In so doing she breaks many taboos treating her royal observers with complete disrespect, addressing them with "winks and nods," using obscene language, and referring openly to sexual matters without any shame. While the nervous Claudius tries to defuse the subversive potential of her behaviour, Horatio, like the Gentleman, realises that her conduct is not a purely domestic matter and may "strew dangerous conjectures in illbreeding minds." Just as Lucibella shows a mad prescience in recognising the guilt of Hoffman and Lorrique before the others present are aware of it, so Ophelia's cryptic utterances and her pointed distribution of flowers suggest an unconscious awareness of the dangerous secrets troubling the Danish court. Claudius calls Hamlet's condition "turbulent and dangerous lunacy" (3.1.4); Ophelia's madness, for all the prettification often misleadingly associated with it, is not totally different. She may "strew $\mid$ Dangerous conjectures in ill-breeding minds" (4.5.14-15). The conversation of the Gravedigger and his companion in 5.1 about her death and the fact that "great folk[...] have countenance in this world to drown or hang themselves more than their even-Christen" (5.1.27-29) indicates a level of critical scrutiny circulating around the court and its environs to which the official handling of Ophelia's madness and death contributes. ${ }^{15}$

Ophelia's mad language, like Lucibella's, is fanciful and freely imaginative; it is also open and licentious in ways unavailable to her when sane. Its sexual content - not shared by Lucibella - is only one aspect of this; she can also refer to taboo subjects such as the "hugger-mugger" manner in which her father's death was hushed

\footnotetext{
${ }^{15}$ MacDonald (1986:309-317) shows that the Gravedigger was right in his view of the privileges accorded to persons of high birth.
} 
up ("which bewept to the grave did not go"), and the potential for this to incite her brother to rebellion. The "matter and impertinency mixed" that characterise stage madness is related by Robert Weimann (1987:119) to the "heritage of non-sensical self-expression" from popular medieval drama. It is a hybrid mode of speech including such elements of verbal patterning as alliteration, wordplay, archaic expressions and proverbs, and nonsense rhymes, commonly found in the language of the Vice, "impertinent" in the sense of "cheeky" as well as not relevant to the matter in hand. It is a popular speech style, and in Hamlet's language, which Weimann discusses, draws on "rural and plebeian experience, images [...] from the most common aspects of every day life" (130). While Weimann is interested to trace the continuity of popular tradition in the mad or "knavish" language of high-born male characters (Hamlet, Lear), he does not mention mad female characters, but their speech shares these characteristics even more conspicuously. License and impertinent speech are common not just to male and female mad characters, but also to both high and low born. In this the highborn women Ophelia and Lucibella are no different from the lowly Jailor's Daughter. All refer to folk tales and proverbs, and, significantly, all sing extracts from ballads; in Q1 Ophelia even makes her appearance "playing on a Lute, and her haire downe singing." ${ }^{\prime 16}$ Singing by the mad is a gendered characteristic; stage madmen do not sing.

Singing itself can exercise a "disruptive and invasive power," acting as an aural sign of estrangement from the normal (Dunn 1994:50). ${ }^{17}$ The form and content of these songs is significant in itself. The ballad in this period had low, plebeian and sometimes rural associations. Lucibella sings her fragment "Lo, here I come awooing, my ding-ding, |Lo, here I come a-suing, my darling,|Lo, here I come a-praying, to bide-a to bide-a, bide- a" (2050-2052), as if she is a travelling pedlar, concluding, "How do you lady? Well, I thank God? Will you buy a bargain, pray? It's fine apparel" (20532054). It has been suggested that the lines "restate the popular, labouring context of the ballad genre" and Ophelia's ballads may

\footnotetext{
${ }^{16}$ See the discussion of the lute in Ann Thompson and Neil Taylor's footnote to 4.5.16, and their account of the music in Appendix 6 to their edition of Hamlet (2006).

${ }^{17}$ Dunn also observes that music is the ideal vehicle to represent "feminine excess" (1994:59).
} 
evoke similar class connotations, suggesting "a realm of childhood, of old, simple ballads sung by the spinners in the sun [...] not the aristocratic ayre, but crude songs of the common folk" (Seng 1967:143, quoting Moore 1916). ${ }^{18}$ She sings extracts from several ballads, many of them about death. But the longest song, which Claudius tries unsuccessfully to interrupt, is explicitly - and in its dramatic context shockingly - about sex and the loss of virginity. ${ }^{19}$

By Gis and by Saint Charity,

Alack and fie for shame,

Young men will do't if they come to't-

By Cock, they are to blame.

Quoth she, 'Before you tumbled me,

You promis'd me to wed.

[...]

'So would I a done, by yonder sun,

And thou hadst not come to my bed. (4.5. 58-66)

She concludes her distribution of flowers, many of them with distinctly unappealing associations of abortion, poison and death, ${ }^{20}$ by singing the line "For bonny sweet Robin is all my joy," where "robin" seems to have been a cant word for penis. ${ }^{21}$ Though she reverts to her appropriate social status as she leaves, calling for her coach and bidding goodnight to the ladies, her distracted speech, in its generic descent to a popular language of licentious freedom, releases the strong emotions she has previously had to suppress.

The madness of Ophelia and Lucibella is interpreted for the audience in the theatre by the witnesses onstage, who attempt to translate its signs into a condition they recognise. In Macbeth and The Two Noble Kinsmen the witnesses of women's distraction include

\footnotetext{
${ }^{18}$ Jenkins, ed. Hamlet (1982:529-536) gives a helpful account of the songs.

${ }^{19}$ Jenkins, ed. Hamlet, notes that this song "is not otherwise known" but the line "Young men will do it if they come to it" is cited as a proverb by Burton in his section on the cure of love melancholy (Anatomy, III. ii.5 (3)).

${ }^{20}$ For instance fennel, rosemary and rue could be used as abortificants, columbines were poisonous, daisies could be associated with artifice and death. See Thomas and Faircloth's dictionary entries on these terms (2014).

${ }^{21}$ The Jailor's Daughter knows the song "Bonny Robin" (4.1.107-109), which is probably the same one. See Potter's note on this in her edition of the play (1997:362). Seng discusses the phallic associations of "robin" (1967:151-153).
} 
doctors, who comment on their symptoms; the women are both so out of control that they are made subject to medical supervision. The language of Lady Macbeth in the sleepwalking scene, with its "jumpcut rhythms" and its incoherent, dream-like quality, has clear similarities with stage madwomen's speech. ${ }^{22}$ Like Ophelia's, it reveals through its lack of conscious control emotions and reactions which she had previously been obliged to conceal, and also, though in a different way, violates taboos. "She has spoke what she should not," observes the Gentlewoman. She too has been witness to a display of violent emotion by a man, when Macbeth is terrorised out of his wits by the appearance of Banquo's ghost, but, in contrast to Ophelia in her view of Hamlet's breakdown, regards the loss of control as the violation of gender norms rather than those of class. ${ }^{23}$ Not knowing the cause of her husband's behaviour, she rebukes him for acting effeminately:

$\mathrm{O}$, these flaws and starts,

Imposters to true fear, would well become

A woman's story by a winter's fire

Authorised by her grandam. (3.4.63-66)

Karin Coddon, discussing the "transgressive ambiguity" of "spectacles of madness" notices here "Lady Macbeth's identification of madness with popular narratives in which folly functioned as a licentious, even anarchic discourse" (Coddon 1989:485-501). Her language in 5.1 is not licentious in the sense of Ophelia's, and she does not sing, although she cries, sighs, groans and starts; but it is incoherent and also referential, with something of the "quoted" quality that Carol Thomas Neely (2004:50) suggests connects mad characters not only with their own pre-history but also with larger themes and cultural associations. She talks openly of what should be secret, in a colloquial prose quite distinct from her usual speech style. "The thane of Fife had a wife" (5.1.36) sounds like a line from a nursery rhyme; "who would have thought the old man to have had

${ }^{22}$ Lady Macbeth's condition is never called madness, although some critics have referred to it as such and actors have played the sleepwalking scene as a mad scene, e.g by Sinead Cusack (RSC, 1986), who gives an account of playing it this way in Rutter (1988:51-72). Charney and Charney (1977:458) call the sleepwalking scene a mad scene "since she speaks in a free-associational, non-rational broken discourse that we expect from Elizabethan madwomen on the stage."

${ }^{23}$ Some critics regard Macbeth's behaviour as bordering on madness, in his hallucination of the dagger and his reaction to Banquo's ghost. See Thiher (1999:77). 
so much blood in him?" (5.1.33-34) in its disrespectful allusion to the dead Duncan refers to the commonplace belief that the blood supply dried up with old age.

The scene, like Ophelia's is a performance, albeit an unconscious one, drawing attention to her "unruly female body" (Chakravarti 2008:141), witnessed and commented on by observers, who in this case make no attempt to intervene. Madness is a condition that is subject to interpretation, and can be read in diverse ways. The comments of the onstage observers may guide the offstage audience in reading the madness, and also on some occasions, as in Hamlet, indicate their own interests and investments in the situation. In Shirley's The Cardinal (1641) the condition of the Duchess Rosaura is described by a lord in advance of her appearance:

She's turn'd a child agen; a madness

That would ha' made her brain and blood boil high

In which distemper she might ha' wrought something. (5.1. 16-18)

The lord is speculating with others here as to whether the Duchess might have involved herself in revenge on the Cardinal for the murder of her husband had she not been mad. What he does not know (though the audience does) is that this madness is a contrivance and his comment alerts the audience to the fact that it is intended precisely to further this revenge. In The Witch of Edmonton (1621), by Rowley, Dekker and Ford, a number of observers comment variously on the madness of Anne Ratcliffe. Mother Sawyer, delighted that her enemy has been driven mad at her request by Dog, laughs at the madwoman's fancies: "Ho, ho, ho! I thank thee, my sweet mongrel" (4.1.177). Anne's husband calls for help in managing her, and his subsequent description of Anne's suicide is robbed of any pathos by the deflating comment of the simpleton Cuddy Banks. Ratcliffe's line, "She beat out her own brains, and so died," is followed by Cuddy's summation, "It's any man's case, be he never so wise, to die when his brains go awoolgathering" (4.1.208-210).

In Macbeth one of the observers of female distemper is present in a professional capacity - the doctor who has been engaged to treat Lady Macbeth and takes notes of the encounter. Timothy Bright in his Treatise of Melancholie (1586) accepts that a condition with physical causes, what he calls "natural melancholy," could display 
the same symptoms as one with spiritual causes (Bright 1586:iii and 187-198), ${ }^{24}$ such as "afflicted conscience," and the Doctor is in no doubt as to which it is here: "This disease is beyond my practice [...] More needs she the divine than the physician" (5.1.59, 64). ${ }^{25}$ Both Doctor and Gentlewoman are well aware of the delicacy of the situation, and careful not to implicate themselves in any potentially treasonous utterances. Like Ophelia's mad speech, Lady Macbeth's unguarded language has resonances beyond the private and intimate scene in which it is heard. Duncan Salkeld (1993:112), discussing the connection between madness and subversion in drama of the period, says that "As Lady Macbeth's madness translates into a metaphor for corporate disorder, her presence on the stage becomes a dangerous political symbol." Cornelia in The White Devil when mad comments bitterly on the dead body of her son Marcello, linking his death with the play's major themes of social aspiration:

His wealth is summ'd, and this is all his store:

This poor men get; and great men get no more,

Now the wares are gone, we may shut up shop. (5.4.106-108)

At a different level, even a common woman like Anne Ratcliffe may in madness be a mouthpiece for social comment; she observes satirically that "All the golden meal runs into the rich knaves' purses and the poor have nothing but bran," and longs to scratch the faces of lawyers.

In The Two Noble Kinsmen the madness of the Jailor's Daughter, who like Anne Ratcliffe is given some speeches of out-of-character social satire, has significance beyond her domestic situation; her social status, like Lady Macbeth's, is central to it. Macbeth, as king, makes the implicit connection in 5.3 between his wife's distracted mind and loss of control and the diseased condition of his country. The madness of the Jailor's Daughter is the means by which the play contrasts the tragic-comic chivalric mainplot with the comic subplot

\footnotetext{
${ }^{24}$ Bright stresses strongly that the two conditions cannot be dealt with in the same way.

${ }^{25}$ When Macbeth asks after his wife, the Doctor offers another diagnosis, that she is "not so sick, $[\ldots] \mid$ As she is troubled with thick-coming fancies|That keep her from her rest" (5.3.38-40). The implication here is that she is suffering from a mental disease with humoral causes, but his unease in Macbeth's company suggests that he may be consciously economical with the truth.
} 
in their handling of the key theme of female desire. In this play gender, genre and class form a nexus, which evolves from the very different social status of the two contrasted unmarried young women, the Jailor's Daughter and Emilia. While the "maidenhearted" Emilia cannot bring herself to choose between the two noble kinsmen, both of whom love her, the Jailor's Daughter has no such problem, and falls passionately in love with Palamon. She is a warmly sexual character, a version of the lusty country wench, ${ }^{26}$ but also intensely class-conscious and aware from the first that her desire is hopeless:

Why should I love this gentleman? 'Tis odds

He never will affect me: I am base,

My father the mean keeper of his prison,

And he a prince. (2.4.1-4)

She risks her life and her father's by releasing him from prison, but this does not win his love, and she goes mad. Parallels with Ophelia are commonplace, and Shakespeare and Fletcher no doubt had Ophelia's madness in mind when they wrote the play. ${ }^{27}$ In their madness both sing ballads, speak fancifully, are sexually preoccupied and express anxieties about the loss of virginity, quote proverbs, ignore the attempts of onlookers to engage with them, and give rein to unfettered and bawdy imagination. Observers are anxious about their behaviour, yet try to aestheticize it. A Friend calls the Jailor's Daughter a "pretty soul" and the Doctor comments, "How prettily she's amiss!", "How her brain coins!" Gertrude's poetic elegy for Ophelia, which connects female madness, flowers, and death by water, is closely paralleled by the Wooer's lyrical description of the Jailor's Daughter singing and weeping for Palamon beside a lake; like Ophelia, she makes garlands for her hair, and tries to drown herself.

The place

Was knee-deep where she sat; her careless tresses

A wreath of bulrush rounded, about her stuck

Thousand fresh water-flowers of several colours,

\footnotetext{
${ }^{26}$ Such figures were standard types in ballads of the period. See Capp (2004:13) and Wiltenberg (1988:101-127).

${ }^{27}$ Both Shakespeare and Fletcher were involved in writing the part of the Jailor's Daughter. See Potter, ed. The Two Noble Kinsmen (1997:24-31). Of the scenes in which the Daughter appears Shakespeare wrote 2.1 and probably 3.2, Fletcher the rest.
} 
That methought she appeared like the fair nymph

That feeds the lake with waters, or as Iris

Newly dropped from heaven. (4.1.82-88)

But there are of course differences, not the least of which is that the Jailor's Daughter is saved from drowning by the Wooer, more proactive in this situation than Gertrude. Her madness is much more expansively treated than Ophelia's, and the progress of her mental breakdown traced through four soliloquies. For a lower-class female character in a subplot she is given an extraordinary amount of stage time, and Douglas Bruster is correct to call her "a pivotal figure" $(1995: 277){ }^{28}$ Bruster rightly notices "the class valences of her idiolect" (282) (though he does not make much of the fact that her four soliloquies are in verse and she is very eloquent). He distinguishes her language from Ophelia's: "Her speech is more directly about her body, and bodies generally, because in dramatic representations of her social stratum, neither madness nor bawdy is typically phrased in decorative poetry" (282). Nonetheless, she is given some "decorative poetry," just as Ophelia speaks bawdy, and the similarities are important. $^{29}$ The major component in differentiating the Jailor's madness from Ophelia's is genre, in which social class is a subsidiary component. Because the Jailor's Daughter is a comic character she is allowed to be rescued from drowning, and given a (more or less) happy ending. The Doctor, brought in for consultation by the worried Jailor, at first makes a diagnosis like that of Lady Macbeth's doctor: "I think she has a perturbed mind, which I cannot minister to" (4.3.6o). But once the Wooer has suggested that there might be some money in it for a cure, he quickly comes up with a course of treatment, involving the Wooer's systematic impersonation of Palamon. This does the trick, even when, despite the Jailor's scruples, the Wooer is advised to sleep with the Daughter, still in the guise of Palamon. In the end, Jailor, Doctor and

\footnotetext{
${ }^{28} \mathrm{I}$ am greatly indebted to this important article.

${ }^{29}$ The Daughter's description of herself as "moped" (3.2.25), having neither eaten nor slept for two days while hunting for Palamon in the woods, is not necessarily a term that distinguishes her condition as lower class. Richard Napier, in McDonald's account, regarded mopishness, a "disturbance of the sensitive faculty, rather than the reason" (163), as a condition similar to but less severe than melancholy. Shakespeare's other uses of the term and its cognates (The Tempest 5.1.237-240), Henry V 3.7.142-144, Hamlet 3.1.78-81) do not apply it to lower class characters. The Doctor calls her condition "a most thick and profound melancholy" (4.3.50).
} 
Wooer collude in the deception, and the Wooer and Daughter depart the stage with sex, rather than as for Ophelia and Lady Macbeth, death in prospect.

The Doctor's diagnosis, that the daughter can be cured of her madness through sex, was distinctly in line with early modern views on young women's sexuality and their tendencies to green sickness, and not necessarily inflected by social class. ${ }^{30} \mathrm{He}$ is, as Mary Beth Rose (1988:226) comments, "more successful at regulating sexuality in the Jailor's world than Theseus is in his court," and the handling of sexuality and virginity in the rural world of the subplot is more humane than in the chivalric society of the mainplot, where the virginal Emilia comments bitterly, "Oh, better never born|Than minister to such harm!" (5.3.65-66) as she listens to the sounds of the joust in which the kinsmen fight to the death for her hand. "Is this winning?" (138) she exclaims after Arcite's victory. Her bitterness for the imminent death of Palamon, the loser in the contest, predominates over any feeling of triumph. The play's bi-fold structure allows that the green world of the subplot may, as it does in A Midsummer Nights' Dream, offer a meaningful alternative to the colder world of the court, and the plebeian Daughter's mad eloquence a warmly imaginative and liberated language against the high-born Emilia's tight-lipped suffering.

Fletcher's The Pilgrim (?1621) offers a coda on the depiction of women's madness and social class. Alinda, a gentleman's daughter, takes refuge in the woods in boy's disguise to escape from her tyrannical father's attempts to marry her off to the arrogant Rodrigo and find her lover Pedro. Lost and hungry, she is taken to a madhouse, "a little craz'd, distracted" (3.7.134), , from which she escapes wearing the she-fool clothes of Kate, one of the resident madwomen, who works in the kitchen. In boy's clothes, Alinda is "a

\footnotetext{
${ }^{30}$ Capulet in Romeo and Juliet calls Juliet a "green-sickness carrion" (3.5.156) and regards immediate marriage as the cure. Burton, III .ii .5(5), has a long chapter called "The last and best cure of Love-Melancholy is, to let them have their Desire." Wiltenberg (1988:12) cites ballads like "The Mayden's Lamentation for a Bedfellow" (Pepys Ballads 1.67) where a doctor prescribes getting a husband "without all delay" as the cure for greensickness. Charney and Charney (1977:458), cite motif F950.4 "Marvels" in Stith Thompson's Motif-Index of Folk Literature (1932-1937) as a traditional folk motif of "sickness (madness) cured by coition."

${ }^{31}$ Quotations are taken from The Dramatic Works in the Beaumont and Fletcher Canon, ed. Bowers (1985), vol. 6 .
} 
pretty lad" and treated sympathetically, while the "real" madwoman Kate is abused and insulted. But once outside the madhouse and apparently a she-fool, Alinda no longer seems so appealing. Neither her father nor Rodrigo recognises her, and they subject her to the sort of abuse meted out to the lower-class Kate, calling her "an arrant fool, an ignorant thing," "puppy," "puppet" and "the devil in a fool's coat." Rodrigo even refers to her as "it" despite acknowledging her sexual attractiveness: "Is't not a Faiery , or some small hobgoblin?|It has a mortall face, and I have a great mind to it $[. .$.$] it is a handsome thing, | But horribly Sun-burnt" (4.2. 29-33) He$ treats the disguised Alinda as he might a servant, as the reference to her sunburn (which a gentlewoman would not have) confirms. Playing the madwoman means that Alinda adopts certain mannerisms: she speaks and acts childishly, fantasises freely, and "coins" in the way that so amazes the Doctor in his observations of the Jailor's Daughter. She also uses her madness as a means of making subversive comments, addressing Rodrigo in such riddling terms as to make him think she may be "a kind of Sibill, some mad Prophet" (4.2. 50). She sings a verse from a well-known ballad, "The Knight and the Shepherd's Daughter" about the seduction of a lowborn girl by a knight ${ }^{32}$ which Rodrigo at once applies to himself: "Tis the meer Chronicle of my mis-haps" (4.2.68). Alinda's scenes, which belong to the romance strand of the play, are set against farcical scenes in the madhouse where the "real" madwoman Kate (along with a group of assorted bedlamites, a parson, a scholar, a drunken Englishman, a Welshman, chained in their cells) is confined. Unlike the condition of the bedlamites, who are shown as caricatures, comic but incurable, Alinda's briefly assumed madness is empowering, enabling her to confront her father and Rodrigo with truth-telling, and paving the way to her happy ending.

While madness is only temporarily empowering for most female madwomen, and in many cases is an immediate prelude to death, it is linguistically liberating, creating for the theatre audience that "exhilarating sense of freedom which transgression affords," as Stallybrass and White (1986:201) put it in their account of the interplay between freedom and restraint in social formations. Madwomen's characteristic speech is extravagantly metaphorical, imaginative, often childish, free of logic and restraint; in its free-

${ }^{32}$ This is number 110 in Child's compilation. 
associational style it often violates rules of grammar and syntax. It is constructed from a medley of voices, weaving together quotations from proverbs and sayings, fragments of songs and ballads, puns, innuendo and word-play. It brings together high and low cultural discourses in a carnivalesque suspension of linguistic norms. It bespeaks a condition in which the distinctions of social class and rank are endangered, and sometimes completely dismissed. In these ways, women's mad language achieves a different sort of "impertinency" from men's, more transgressive and licentious because more norms are violated. In The Two Noble Kinsmen the countrymen are delighted to come upon the Jailor's Daughter, "a dainty madwoman [...] mad as a March hare" (3.5.73-74), to lead their dances; playwrights of the period may well have found that the inclusion of scenes for madwomen similarly enlarged the possibilities of their plays.

\section{References}

Bakhtin, Mikhail 1984. Rabelais and his World. Trans. Helene Iswolsky. Bloomington: Indiana University Press.

Bright, Timothy 1586. A Treatise of Melancholie. London.

Bruster, Douglas 1995. "The Jailor's Daughter and the Politics of Madwomen's Language." Shakespeare Quarterly 46/3: 277-300.

Burton, Robert 1972 (1621). The Anatomy of Melancholy. Ed. Holbrook Jackson. London: J. M. Dent and Sons.

Capp, Bernard 2004. When Gossips Meet: Women, Family, and Neighbourhood in Early Modern England. Oxford: Oxford University Press.

Chakravarti, Paromita 2008. "'I have no other but a woman's reason': Folly, Femininity and Sexuality in Renaissance Discourses and Shakespeare's Plays." The Shakespearean International Yearbook 8: 136-161.

Charney, Maurice and Hanna Charney 1977. "The Language of Madwomen in Shakespeare and his Fellow Dramatists." Signs 3/2: 451-46o.

Chettle, Henry 1951 (1631). The Tragedy of Hoffman. Ed. Harold Jenkins. Oxford: The Malone Society Reprints.

Child, Francis James 1965. The English and Scottish Popular Ballads. New York: Dover Publications.

Coddon, Karin S. 1989. "'Unreal Mockery': Unreason and the Problem of Spectacle in Macbeth." ELH 56/3: 485-501. 
Dawson, Lesel 2008. Lovesickness and Gender in Early Modern English Literature. Oxford: Oxford University Press.

Dunn, Leslie C. 1994. "Ophelia's Songs in Hamlet: Music, Madness and the Feminine." Eds. Leslie C. Dunn and Nancy A Jones. Embodied Voices: Representing Female Vocality in Western Culture. Cambridge: Cambridge University Press: 50-64.

Fletcher, John 1621? The Pilgrim. Ed. Fredson Bowers. The Dramatic Works in the Beaumont and Fletcher Canon. Vol. 6. Cambridge: Cambridge University Press.

Foucault, Michel. 1971. Madness and Civilization: A History of Insanity in the Age of Reason. Trans. Richard Howard. London: Tavistock Publications.

Henslowe, Philip 1961. Henslowe's Diary. Ed. R. A. Foakes and R. T. Rickert. Cambridge: Cambridge University Press.

Iyengar, Sujata 2011. Shakespeare's Medical Language: A Dictionary. LondonNew York: Continuum.

Kyd, Thomas 1970 (1590?). The Spanish Tragedy. Ed. J. R. Mulryne. London: 1970.

Lecercle, Jean-Jacques 1990. The Violence of Language. London and New York: Routledge.

Levin, Harry 2004. "Two Scenes from Macbeth." Macbeth. Ed. Robert S. Miola. New York and London: W. W. Norton and Company: 266-282.

MacDonald, Michael 1981. Mystical Bedlam: Madness, Anxiety and Healing in Seventeenth-century England. Cambridge: Cambridge University Press.

— 1986. "Ophelia's Maimed Rites." Shakespeare Quarterly 37/3: 309-317.

Marlowe, Christopher 1981 (1590?). Tamburlaine. Ed. J. S. Cunningham. Manchester: Manchester University Press.

Moore, John Robert 1916. "The Function of Songs in Shakespeare's Plays." Shakespeare Studies by Members of the Department of English of the University of Wisconsin. Wisconsin: University of Wisconsin Press.

Neely, Carol Thomas 2004. Distracted Subjects: Madness and Gender in Shakespeare and Early Modern Culture. Ithaca and London: Cornell University Press.

Peterson, Kaara L. 2010. "Portraying Shakespeare's Hysterics." Mosaic 34/1: 35-59.

Rutter, Carol, ed. 1988. Clamorous Voices: Shakespeare's Women Today. London: The Women's Press.

Rose, Mary Beth 1988. The Expense of Spirit: Love and Sexuality in English Renaissance Drama. Ithaca and London: Cornell University Press. 
S. Clark

Salkeld, Duncan 1993. Madness and Drama in the Age of Shakespeare. Manchester: Manchester University Press.

Seng, Peter J. 1967. The Vocal Songs in the Plays of Shakespeare. Cambridge, MA: Harvard University Press.

Shakespeare, William 1982 (1603). Hamlet. Ed. Harold Jenkins. London and New York: Methuen.

2006 (1603). Hamlet. Eds. Ann Thompson and Neil Taylor. London: Thomson Learning.

— and John Fletcher 1997 (1613). The Two Noble Kinsmen. Ed. Lois Potter. London: Thomas Nelson and Sons Ltd.

Shirley, James 1986 (1641). The Cardinal. Ed. E. M. Yearling. Manchester: Manchester University Press.

Stallybrass, Peter and Allon White 1986. The Politics and Poetics of Transgression. London: Methuen.

Thiher, Allen 1999. Revels in Madness: Insanity in Medicine and Literature. Ann Arbor: University of Michigan Press.

Thomas, Keith 1973. Religion and the Decline of Magic. Harmondsworth: Penguin Books.

Thomas, Vivien and Nicki Faircloth 2014. A Dictionary of Plants and Gardens in Shakespeare. Arden Shakespeare Dictionaries. London: Bloomsbury.

Thorndike, Ashley, H. 1902. "The Relationship of Hamlet to Contemporary Revenge Plays." PMLA 17/2: 125-220.

Weimann, Robert 1987. Shakespeare and the Popular Tradition in the Theater. Ed. Robert Schwartz. Baltimore and London: Johns Hopkins University Press.

Wiltenberg, Joy 1988. "Madness and Society in the Street Ballads of Early Modern England." Journal of Popular Culture 21/4: 101-127.

How to cite this article:

Clark, Sandra. "Women, class, and the language of madness in early modern

English drama." SEDERI 24 (2014): 7-26.

Author's contact: Sandra.Clark@sas.ac.uk

Submission: 09/10/2013

Acceptance: 18/01/2014 